\title{
The Reconstruction of Gender in Politics
}

\author{
S. Moita, L. R. Handayani \\ Lecturer of Sociology \\ Lecturer of English Literature \\ Universitas Halu Oleo Kendari, \\ moitasulsalman@yahoo.co.id
}

\begin{abstract}
This research aims at examining and analyzing the process of the reconstruction of gender equality in politics, including the role of women as actors and the role of structural conditions in the reconstruction process. In addition, this research was also to find consequences for gender equality towards the reconstruction of relations and gender-responsive in Parliament. This research was qualitative case study approach. In data collection, researchers acted as an instrument of research. The technique of data collection was carried out through in-depth interviews, observation and documentation. The Data was analyzed qualitatively; that was analysis conducted since data collection until the research is completed. The results showed that: the role of women as actor in the reconstruction process of gender equality, in politics includes movement against the political structure which subordinates through the power of internal and individual moral actor, consciousness that encourages rationality politicking, the movement itself in politics, as well as the struggle to compete in the general election. Furthermore, the role of structural conditions in the reconstruction process of gender equality in politics manifests on the role of a number of political institutions, governmental institutions, and a semi non-political socialization, through action field, coaching, mentoring, education, politics, etc. The implications of the role of the actor and the role of the structural conditions produce the consequences of equality of gender relations, reconstruction in Parliament. It consists of resource allocation, control, access, participation, and benefits, as well as the reconstruction of the consequences of gender responsive policies and budget, namely that the institutional strengths, including gender pro through the parliamentary women's Caucus.
\end{abstract}

Keywords: reconstruction, gender equality, political, parliamentary, gender relations, gender-responsive.

\section{INTRODUCTION}

Efforts to encourage gender equality in politics has been articulated [1], that the transformation of world politics towards the 21 st century, one of which is marked by the phenomenon of collapse of the patriarchal order in various parts of the world and the days of feminist discourse in the political arena. These conditions were supported by the political electoral policy for women who have given the significant changes with respect to increased representation of women in Parliament [2].

Globally, the percentage of representation of women in Parliament is relatively varied in a number of countries. Rwanda is a country that has the largest percentage of women who is $35 \%$, then Andorra one of the small countries in the European continent by percentage is $53,6 \%$. United States as a country of democracy, the percentage representation of women is only $16.67 \%$. Countries that have the smallest percentage of women representation is Yemen and Saudi Arabia respectively $0.3 \%$ and $0,0 \%$ [3].

Indonesia as a country that recently attended a reform and democracy in 1998, the percentage of representation of women in Parliament has increased even though it has not been significant if it refers to a number of regulations that encourage women's representation by $30 \%$. For three times, the holding of elections, the percentage of representation of women in Indonesia in 1999 was $9 \%$. In 2004, it was $11,6 \%$ and in 2009 , it was $18 \%$ [4].

Affection to improve the representation of women in politics is an attempt to reach gender equality, including practices of subordination and dominations, which are detrimental to women. Gender regimes that create inequities can be constructed and reconstructed in order to realize gender equality [5] [6]. Gender reconstruction should take into account the position of women in all walks of life, take into account women's experiences, knowledge, attitudes and skills outside the household [7].

Efforts to foster gender equality in the world of politics can also be implemented through the education perspective in gender. The education will encourage the formation of a new individuality so that people are educated to achieve equality between the sexes, without discrimination and exclusion [8]. Gender equality in education gives same opportunities between men and women in economic, social life, culture, and politics [9].

The constitution of a number of regulations in Indonesia after the 1998 reforms that encourage increased representation of women in the political scene is one of the dimensions in order to reinforce the existence of the political education gender perspective. The substance of law No. 12 of 2003 about party politics and Act No. 10 of 2008 about the legislative elections that put at least 30 percent of women as members of the legislative body, can be a starting point for women to increase its participation in the realm of politics.

At the local level, regulation that encourages women's representation in Parliament is appreciated by a number of parties, either in micro-scale or macroscale. Kendari, Southeast Sulawesi province as a location for research, is one of the five districts and 
cities in Indonesia in 2009 Election, that able to place women's representation, which is more than $30 \%$. From a total of thirty members of the legislature, ten of them are women with a percentage of $33 \%$. Achievement percentage of representation of women in Kendari is an indicator of the role of a number of elements either for individual of women themselves, or the factors outside of individuals such as political parties, the Electoral Commission, women's Institutions, and so on.

Configuration of the representation of women in Parliament Kendari is a very interesting phenomenon to be examined especially for the perspective of the sociology of gender and political sociology. On this basis, there are two analysis models were used to examine this research in gender perspective, namely: micro and meso analysis model. Micro-analysis Model put the individual as the unit of his analysis. An explanation of the social definition paradigm considers individuals instead of the object that was created and always ready made targets of external forces, but rather individuals who are active, creative and have the ability to respond to external stimulation are judged detrimental to his interests. Theories that can be used in the model description, is a theory of Phenomenology [10] and the theory of active community [11]. Model analysis of meso is the study that will synergize the debate two great theorists that are the paradigm of social facts and social definition paradigm [12].

Micro-and meso analysis model is then synergized with Reconstructionist thought. This approach appears due to gaps and disillusionment toward the General theories that cannot be "critical." Reconstruction based on two major premises, namely: people need constant reconstruction or change, and social change also is the reconstruction of knowledge as a vehicle for community reconstruction [13]. The reconstruction of the actor dimension encourages awareness and motivation of women in previous elections, only the miners a voice for men.

Study of the reconstruction of gender equality can also be analyzed in the perspective of social movements. Individual acts, manifestations of culture, and increasing awareness, also can be referred to as elements of social movements [14]. Furthermore, the concept of self-help for women can be understood as a social movement: the movement for women's nongovernmental attempting to empower themselves and against gender norms that dominate in everyday life [15]. The movement of individual self-awareness as part of a social movement is also supported by a number of institutions within the framework of the social structure to perform the reconstruction process for gender equality through political education, mentoring, and coaching.

Based on the description above, this research focused on the study of the reconstruction process and the identification of gender equality in politics and the consequences of gender responsive and relations in Parliament, which includes the participation of female politicians in building a balanced relationship and respond to programs and policies that are gender pro.

\section{RESEARCH METHODS}

This type of research was qualitative research that attempted to understand the definition of the individual from the subject researched. Researchers conducted in-depth communication and interaction with the Party examined, including understanding and developing categories, patterns and analysis of social processes that occur in the middle of the community.

The approach in this research was a case study approach. That is the intensive investigation of individual social unit, and conducted in-depth with find all important variables on the development of an individual or social unit, which researched. The study also used supporting informants, namely: Chairman of the Board and member of Parliament, political parties, mass media; Stakeholders who care about gender equality programs, such as the women's nongovernmental organization, the Center for Gender Studies, women Islamic organizations, and organizer of the elections.

According to the source, the data used are divided into two categories, namely primary data and secondary data. Primary data collection techniques were carried out through in-depth interviews to explore the cognitive structures and the world the meaning of behavior of the subjects examined. Researchers also conduct observation to figure out how social behavior examined subjects related to themes that are the focus of research. Secondary Data were obtained through the study of documents, namely the data from relevant agencies such as the Secretariat of the Parliament, political parties, the Electoral Commission, and other written sources.

This study used qualitative data analysis techniques. Qualitative data analysis done by some gradual process, namely: reviewing all the data that has been obtained by reading, studying, and understanding; reduce data by abstraction; collating data in units or classifications, and checking the validity of the data

\section{RESULTS AND DISCUSSION}

\section{A. Actor role (female) in the reconstruction process gender equality in politics}

In this study, the reconstruction of gender equality is a cornerstone of enlightenment and knowledge for women to fight against the yoke of domination. Reconstruction of equality is also interpreted as a movement and a reaction to the marginalization and subordination of women in politics.

The results of the study, explains that moral individuals (actors) become the main force of the reconstruction process of gender equality in politics. Individuals have the motivation and high ideals to fight because of internal factors in the self, such as level of education, professional background, experience of organization, confidence, motivation, self-awareness, competitive capacity, commitment, and so on. The internal factors together and supported by external forces such as political parties, voters, the media, women's organizations, and other stakeholders. 
Social and cultural conditions that influence the role of individuals (actors) in the reconstruction process is the basic capital needed to fight to the legislature. This condition is where the majority of the study subjects agreed that the required capacity of self before running for the legislature. Capacity is a musthave personal inputs into early strength, such as level of education, professional background, and experience of the organization. Significance levels in the study subjects actualize their political progress to be candidates for the legislature, affect cognitive structures include: basic knowledge of politics, a preliminary understanding of the duties and obligations as a member of the legislature, and a high level of confidence to compete.

Professional background that there is a driving force asset value, morals, ethics, and ethos to deliver a person has identity to exist and be known by others to create a reciprocal relationship in political activity. Judging from the aspect of meaning itself as part of the movement for the equivalent, experience of the profession of social capital as well as a social investment so that when converted on political activities will become the political capital. In the aspect of organizational experience, a driving force to break the tradition that politics are generally the only synonymous with men. They realize that without the introduction of the organization, the women cannot understand leadership, discipline, commitment, responsibility, role, and so on. Thus, the importance of the organization, all study subjects agreed that to become politicians in parliament must be supported by the experience of the organization.

Furthermore, purport themselves as a force in the reconstruction process of gender equality in politics, focusing on the birth of an attitude, action, and movement through a similar meaning for themselves. The meaning is the process of how a person's selfcontrol his future with rational action, and the power of self-control possessed. Efforts to control the future by learning autonomously is one part of the process towards reconstruction. In order to maximize the potential of women in politics, takes a strong sense of self, directed, so that the systemic political knots that have been shackling them to be open along with the structural conditions that provide opportunities in the form of regulations, policies, programs and concrete actions.

The research findings show that awareness of the research subject is the power of interest in politics. Political interest of the foundation that political activity is dominated by efforts by potential-potential, both the potential and the potential of the self beyond the self. A number of indicators are the basis for the emergence of consciousness research subjects to participate in the 2009 General Election, among others: lack of political experience, motivation to be equal and political access. On the basis of the political experience encourages selfawareness to participate in politics. The motivation to create the equivalent of a strong ambition, initiative and the ability to direct increased positive energy for the parliament.

Further understanding of the meaning of selfcorrelated with the identity of research subjects in response to the movement as parliamentary politicians. One aspect that gives effect to the female identity is a movement to fight themselves. Movement is a social movement of micro self-centered individual, selfcontained payloads such as ideology, the values of self, self-optimization of resources, and commitment to self. All of the self-motion input, integrated on a firm belief that to realize, understand, and strive for.

The findings of the study indicate a change in the ideology of self-ideological nature of the study subjects into ideology nurture. Ideology nurtures in gender perspective should not be construed as a form of defiance in family life, but it is a form of response to the attitudes and actions that in themselves, there are principles to advance, succeed, and hope the same with men in the political world. Understanding of the role of gender ideology, can affect female voters to support candidates of women legislators [16].

Relating to valuing them, agreed that the study subjects them not merely as potential but must be actualized through empowerment to the fullest by looking at the focus and expected outcomes. The study findings suggest that, all study subjects could understand the typology of voters, especially women voters, so that when the political socialization and interaction interwoven political communication expected by the voters. Women gain a strategic advantage when associate themselves as candidates by emphasizing socialization of women legislators on women's issues [17]. Synergy with self-optimization of resources, the study subjects agreed that the potential level of education, organizational experience, and work experience should be maximized in order to determine the ability of the public figure legislative candidates. The importance of resources for research subjects themselves are very aware, because without it, they do not have enough references to prove to the public that they have the ability and capacity to compete.

The latter is a significant commitment agreement to perform whole hog. As legislative candidates in the 2009 General Election, the first step of the growing commitment. The study subjects realize that the choice of a legislative candidate is the responsibility to fight for the banner bearers of political parties with regard to ideology, vision, and mission of the party. In order to realize self-commitment, conduct research subjects ranging from the political strategies of political communication strategies, forming a successful team, setting up the infrastructure, public opinion strategies, use of media, as well as colleagues and institutional support.

Further study subjects struggle, together with the existence of social and political structures as a field in which individuals reflect their political behavior. The study findings suggest that there are three forms of the struggle of the study subjects in the 2009 elections, namely: the stages of registration or nomination, campaign phases and stages of voting. Domination stage is the stage of registration as a candidate for the legislature to complete all administrative requirements based on existing regulations. Phase of the study subjects did campaign concrete efforts to get voters through campaign dialogue, of media campaigns, and rallies, that when someone does a political campaign, he 
must first have a political investment that is better known by constituents. Furthermore, the voting phase is the most crucial stage of all stages of the election because this is where the capacity of the subjects tested, whether he is trusted by constituents in regional election [18].

\section{B. Role of structural factors affecting the reconstruction process in gender equality in politics}

Assessment of synergy between the structure and dynamics of the actors in the political life of women in parliament, most cannot be explained in the analysis [12]. Be an access structure for actors to strengthen the capacity of political opportunities and while the actor is a person with an identity and independence can control various regulations, programs, and policies. Research on gender equality in the political reconstruction confirms that the position of the actors (research subjects), integral with the position of the structure. Both entities are complementary, and the synergy that the ideals and expectations of women's appearance on the political stage can be achieved.

The study's findings reveal the structural conditions that influence the reconstruction of gender equality in the political struggle, action, commitment, and synergy to create a situation where women can take on the role and opportunities as legislative candidates. Institutions that influence significantly to the reconstruction effort; either institution directly related to political processes such as the Election Commission and political parties and institutions that have the commitment and responsibility of promoting gender equality, such as the Women's NGO, the Centre for Gender Studies, Religious Organizations, and the media.

Other significant political institution in reconstruction process push gender equality in Parliament is a political party. Research findings show that the political party winning seats in Parliament Kendari do four roles, namely: cadre recruitment in the stewardship of the party, the nomination of women as members of the legislative, policy and political strategy against potential women, and the role of political parties in increasing competence and capacity of the members of the legislature for women. For specific strategies against the members of the legislature for women, in General, political parties put the important attention with intense socialization do either through the media or directly in the community. Political parties also provided a legislative candidate head of a supply of women regarding strategies to compete, political communications, strategy and won the election with packing issues sensitivity of gender.

Furthermore, significant structure element as a vehicle of socialization and political education is the media. The existence of the media, not only to give information and publishing activities performed by individuals, groups, and organizations but media can also affect the formation of public opinion. Specifically, the media can be a vehicle of political marketing for political parties to introduce the candidates who competed for the women politicians Parliament seats.
Research findings suggest there are three indicators that use the media to influence the reconstruction of gender equality in politics, namely: dissemination through broadcast or news, the socialization through public service announcements, and socialization through special programs or rubric.

With regard to the role of women stakeholders, indicate that there are institutions that also gives women stakeholders contribution toward efforts to gender equality in politics, namely: NGO/Non-Governmental Organization (LSM/Lembaga Swadaya Masyarakat) comprising Women Coalition of Indonesia, Alliance of women, and female solidarity; the Centre of Gender Studies in Halu Oleo University and University of Muhammadiyah; as well as women's organizations, namely the Aisiyah Southeast Sulawesi.

Womens' NGO are the most consistent stakeholder, reactive, and structured in the fight for gender equality in politics. The networks, not just local and national based; however, integrated with international networks. The various efforts and initiatives of womens' NGO strategy has been carried out starting from the response and reaction to the regulation governing the representation, to do political education, mentoring, protection, debriefing, socialization. Even it is including doing sporadic actions field for uploading a public awareness of the importance of the relationship between men and women in the political sphere. Elaborating on research findings a number of womens' NGO movement in order to encourage gender equality in the 2009 general election, namely: socialization, recommendations and actions field, debriefing, political mentoring, building, coalitions/networks, that the establishment of the network will facilitate the mobilization of support for the increased representation of women in Parliament [19].

A component of other stakeholders who participated and contributed to efforts to encourage gender equality in politics is the Center of Gender Studies in Universitas Halu Oleo and Universitas Muhammadiyah. Research findings indicate that both the study center is committed to fostering gender equality in politics through research, study, discussion forums, and talk show. Center of Gender Studies can also build synergy and cooperation to enhance the capacity of members of the legislative post elected women through protection agenda, mentoring, and maximize the potential of women's parliamentary caucuses in pursuit of the development the agendas that pro gender.

The next religious organization that contributes in an attempt to encourage gender equality is Organization of Aisyiah. Research findings show that, the Organization of Aisyiah in Southeast Sulawesi has political education programs of women. This program is not empirically encouraging cadres to affiliate on a particular party to be politicians. But political education directed to giving enlightenment that women need more intelligently choose a political party according to the struggle of the organization. The Organization of Aisyiyah also encourages and supports the caretaker and cadres who want to join in a party or being members of the legislature to use the political 
means that are polite, civilized, and favors the interests of the community.

\section{The consequences of the reconstruction of gender equality in politics affects the pattern of relation and gender responsive in parliament}

The efforts to achieve justice and gender equality in politics in the context of social reconstruction, not only fulfil the percentage of women representation in Parliament, but whether the representation of correlated implementation are tasks and functions of the Parliament. The empirical bases there are two things that become the focus, i.e. the consequences of gender relationships and consequences of gender responsive.

The consequences of gender relations are the position of women as subjects of discussion of proactive duty and the authority of the legislature. Women as representatives of the people can demonstrate the capacity, competence, and its potential for parallel, designed and built to maximize the functions of Parliament, as well as carrying out the aspirations of the community. Whereas the consequences of gender responsive is efforts to respond to the program, policy, and budget pro gender on the basis of both the initiative and the struggles of women's legislative as well as on the basis of shared commitment of members of Parliament.

With regard to gender relations, research findings indicate that the five forms of relationship that is able to do by women parliamentarians of Kendari, namely: First, the allocation of resources, which appears on balance on the position on the parliamentary position of fittings in the special committee, and the position within the faction. Especially to the post of head of Parliament; three positions two of them on the lead by women each as Vice Chairman. Second, access, seems on balance in the process of lobbying and discussion of budgets did networking aspires. Thirdly, participation, the women's Parliament is quite active in the participation of parliamentary conferences, hearing, and in receiving the aspirations. Fourth, control, the ability of female members of parliament in controlling varieties of programs \& executive decisions and conduct consultations \& coordination. Fifth, the benefits gained through capacity building and strengthening relationships with constituents.

Furthermore, with regard to gender responsive, research findings suggest that the existence of a fellow Member of the female legislators in the Parliament of Kendari quite budget fight for proactive and pro women programs on any discussion of the budget, both in the Commission, the Agency's budget, the plenary meeting as well as meetings of the plenary. During the last three years an elected member of the legislature, graduate women were able to raise a women's pro development budget of up to $500 \%$.

Women are also members of the legislature, through the parliamentary women's caucus vehicle in Kendari was able to push out a number of local regulations in favour of the interests of women, such as local regulations on the protection of women and children, local regulations concerning gender mainstreaming, and local regulations regarding proper city kids. The existence of women's parliamentary caucus in Kendari, the parliamentary women's caucus that will strengthen the voice of women in Parliament in the advocate for the rights of women and encourage the pro gender development policy [20] [21].

\section{CONCLUSION}

The research showed: first, the role of the actor in the process of the reconstruction of gender equality in parliament is the accumulated struggle through the power of self and individual moral, awareness reflection, motivation, and the movement itself to compete the election in 2009 which implies success into parliamentary politicians. Second, the role of structural factors such as the Commission on Elections, political parties, women's' NGO, the Center for Gender Studies, women's organizations, media, also affect the process of the reconstruction of gender equality in politics through the role of socialization, political education, accompaniment political, debriefing political, recommendations, actions field, and strengthening the capacity of institutional through Parliamentary Women Caucus. Third, the synergy of self-awareness, movements, and individual struggles (actor) and support the structural conditions affect the consequences of gender relation reconstruction and gender responsive. Consequences for gender relations to generates the balance in the implementation of basic tasks and functions of Parliament through the allocation of resources, access, participation, control and benefits; whereas the consequences of gender responsive namely programming its realization, advocacy and gender budgets pro.

\section{REFERENCES}

[1] Castells, M., 2004. Power of identity. Blackwell Publishing, Oxford.

[2] Jalzai , Farida and M. L. Krook, 2010. Beyond Hillary and Benazir: Women's Political Leadership Worldwide. International Political Science Review, 31 (1): 5-21.

[3] Vetten, Lisa, Makhunga Lindiwe and Leisegang Alexandra, 2012. Making Womens's Representation in Parliament Count: The Case of Violence Against Women. Womandkin and Euoropan Union.

[4] Irmayani, T. and Imelda, F.P.O., (2009). Perempuan Berpolitik. Jurnal Politeia, 1 (2): 120-126.

[5] Walby, S., 1999. The New Regulatory State: The Social Powers of the European Union. British Journal Socioloy, 50 (1): 118-140.

[6] Beauvior, Simone De. 1989. Second Sex: Kehidupan Perempuan. Pustaka Promothea, Yogyakarta.

[7] Raditloaneng, W.N., 2013. Towards a Transformative Reconstruction of Gender: A Critical Review of Women in the International Space. International Journal of Sociology and Anthropology, 5 (2): 50-58.

[8] Hernandez, M.R.N., P.I.R. Gonzalez and S.V. Sanchez, 2013. Gender and Constructs from the Hidden Curriculum. Creative Education, 4 (12B): 89-92.

[9] Sahin, Elmas, 2014. Gender Equity in Education. Journal of Social Sciences, 2: 59-63.

[10] Kuswarno, Engkus, 2009. Fenomenologi (Konsepsi, Pedoman, dan Contoh Penelitian). Widya Padjadjaran, Bandung.

[11] Poloma, M. Margareth, 2007. Sosiologi Kontemporer. Yayasan Solidaritas Gadjah Mada, Yogyakarta.

[12] Giddens, Anthony, 1984. The Constitution of Society-Outline Of The Theory Of Structuration. UK-Polity Press, Cambridge. 
[13] Hamalik, Oemar, 2007. Dasar-Dasar Pengembangan Kurikulum. PT Remaja Rosdakarya, Bandung.

[14] Hooghe, March, 2013. "Social Movement" in 21 st Century Political Science: A Reference Handbook; John T. Ishiyama, Marijke Breuning; University of North.

[15] Taylor, Verta and Marieke.V.W., 1996. Women's Self-Help and the Reconstruction of Gender: The Postpartum Support and Breast Cancer Movements. A Internasional Journal, I (2): 123142.

[16] Muluk, Hamdi, 2006. Peranan Faktor Gender, Isu Politik, dan Identifikasi Partai Politik pada Pemilihan Calon Legislatif Perempuan. Jurnal Penelitian Psikologi, 11 (2): 111-119.

[17] Hermson,P.S., Lay, J.C., and Stokes A.K., 2003. Women Running "as women": Candidate Gender, Campaign Issues, and Voter-Targeting Strategies. The Journal of Politics, 65 (1): 244-255.

[18] Sulaiman, A.I., 2010. Realitas Politik Perempuan sebagai Komunikator Politik. Jurnal Mimbar, 26 (1): 59-70.

[19] Bassar, Emilia , 2008. Perempuan dan Pemilihan Umum (Strategi Komunikasi dan Pendidikan Politik Pemilihan Umum 2009 pada Perempuan). Jurnal Semiotika, 2: 13-25.

[20] Markhan, Susan , 2012. Strengthening Women's Roles in Parliaments. Parliamentary Affairs Advance Access Published, 10: $1-11$.

[21] Mutamba, John and Izabiliza, Jeanne, 2005. The Role of Women in Reconciliation and Peace Building in Rwanda: Ten Years After Genocide. NURC. 